\title{
Syrian refugees' perspectives and service providers' viewpoints on major needs and future plans in Jordan
}

\author{
Mitra Naseh ${ }^{1 *}$ D, Natalia Liviero ${ }^{2}$, Maryam Rafieifar ${ }^{3},{\text { Zahra } \text { Abtahi }^{4} \text { and Miriam Potocky }}^{3}$
}

\begin{abstract}
The ongoing civil war in Syria created the world's largest refugee crisis since World War II. As exile continues for many Syrians, this study aimed to explore what refugees perceive as their major needs and plans for the future in comparison to what service providers believe is needed and should be planned in Jordan. Phenomenological design and inductive reasoning were used in this study to explore refugees' needs and future plans from the etic view by interviewing key informants and from the emic view by analyzing interviews with refugees. After coding and comparing the key informants' interviews and refugees' narratives, six main themes emerged: (1) gap between refugees' expectations and reality of humanitarian services; (2) rent as a major but neglected challenge; (3) older adults: vulnerable and at the back of the queue for services; (4) mental health of adults as an overlooked need; (5) education: hard to access for extremely poor and adults; and (6) an uncertain and unplanned future. Findings suggest a need for better information sharing strategies about services, targeted programs for urbane refugees and older adults, awareness-raising about importance of the mental health and protracted exile, and long-term planning.
\end{abstract}

Keywords: Refugee, Qualitative, Wellbeing, Syrian, Jordan

\section{Introduction}

The conflict in Syria started as a nonviolent uprising in March 2011 and rapidly turned into a civil war and became the cause of the world's largest refugee crisis since World War II (Aziz et al. 2019; Jabbar and Zaza 2016; O'Rourke 2014). When the uprising began in Syria, many planned a short stay in Jordan, the neighboring country with which it shares a 379-km border (Al-Qdah and Lacroix 2017; Aziz et al. 2019). Shortly after the uprising began, the situation escalated in Syria and resulted in an exponentially growing number of refugees crossing the border into Jordan (Al-Qdah and Lacroix 2017; Human Rights Watch 2018; The Regional Refugee and Resilience Plan for the Syria crisis 2018). An unprecedented rate of 6000 border crossings per day from Syria

\footnotetext{
* Correspondence: mitra.naseh@pdx.edu

${ }^{1}$ School of Social Work, Portland State University, Portland, USA

Full list of author information is available at the end of the article
}

to Jordan was reported in 2013 (Boswall and Al Akash 2015). Estimates show that as of December 2017, around 1.4 million Syrians lived in Jordan, of which over 680, 000 were registered refugees (Rizkalla and Segal 2018).

Jordan is not a signatory to international conventions protecting the rights of refugees including the 1951 Refugee Convention and its 1967 Protocol (UNHCR 2015). Instead, the country's legal framework for refugees falls under the 1998 Memorandum of Understanding between the United Nations High Commissioner for Refugees (UNHCR) and the government of Jordan (Aziz et al. 2019). The government of Jordan initially welcomed Syrians under this memorandum using an open-border policy, but gradually put limitations on admission of refugees and their access to services (Aziz et al. 2019). In the past years, Syrians who had friends or family members in Jordan commonly have joined them in urban areas, and those with limited to no social 
network or financial resources were relocated to refugee camps (Wall et al. 2017). Over 50 governmental and non-governmental organizations (NGOs) are present in refugee camps in Jordan and provide services (Wall et al. 2017). Despite the fact that services are free of charge in camps, only around $20 \%$ of Syrian refugees live in these settings (Abu Hamad et al. 2017; Al-Qdah and Lacroix 2017). Refugees' reluctance to live in camps is partly due to limited livelihood opportunities and partly due to lack of privacy caused by communal areas and the government monitoring system (Wall et al. 2017).

Jordan is a developing country with limited resources. The economic fatigue caused by the refugee crisis has stretched the already scarce resources of the country and consequently pushed many Syrians living in Jordan into poverty in recent years. According to the available data, the majority of Syrian families in urban areas of Jordan live below the national poverty lines (Abu Hamad et al. 2017; Rizkalla and Segal 2018; The Regional Refugee and Resilience Plan for the Syria crisis 2018). A vast majority of Syrians had to spend the savings that they brought from Syria in early years after their arrival in Jordan and as exile continues, they have been left with minimum financial resources (Culbertson et al. 2016). Moreover, the shortage of affordable housing in Jordan makes living for those in poverty more challenging in urban areas (Aziz et al. 2019). Rent costs were found to be excessive and increasing in Jordan, forcing many refugees to live in substandard housing (Culbertson et al. 2016; Tiltnes et al. 2019; Wells et al. 2016).

Reports show that while humanitarian actors are dramatically underfunded (The Statistical, Economic and Social Research and Training Centre for Islamic Countries 2016), Syrian refugees still heavily rely on assistance provided by these organizations (Hamdan-Mansour et al. 2017; Rizkalla and Segal 2018). A report by Achilli (2015) explained that the most vulnerable groups, such as older adults, may not be able to afford renewing their refugee cards due to extreme poverty and end up being excluded from already limited humanitarian services.

Considering the limited relief resources and growing needs of Syrians as exile continues, we were interested to learn if available services are in line with what refugees believe is needed. In this context, we designed a qualitative study to explore what refugees perceive as their major needs and plans for the future in comparison to what service providers believe is needed and should be planned for. In this study, we focused on the urban refugee population, as the majority of Syrians live in urban areas. We collected our data through semistructured interviews with six service provides and 11 Syrian refugees. The Caritas Internationalis center for Syrian refugees helped us to recruit our sample in Amman, the capital city of Jordan, home to around one in every three Syrians in Jordan (Al-Qdah and Lacroix 2017; Connable 2015).

\section{Methods}

We conducted a phenomenological research using inductive reasoning (Rubin and Babbie 2016) to document and compare perspectives of Syrian refugees and service providers in Amman on major needs and plans for the future. We interviewed service providers to study the living situations and major needs of urban refugees from the etic view (Morris et al. 1999) and we analyzed collected interviews with Syrian refugees to explore their needs and future plans from the emic view (Morris et al. 1999). Interviews with refugees and service providers were semi-structured allowing the interviewers to use an interview guide with main questions and probes on certain issues that needed more information (Abu Hamad et al. 2017; Rizkalla and Segal 2018).

\section{Sample}

After receiving approval of the institutional review board, we used purposive and snowball sampling methods to recruit service providers working with Syrian refugees in Jordan as key informants. We aimed to have anonymous interviews with at least five service providers as recommended by Creswell and Poth (2018) for phenomenological research. Similar to the method used in our earlier study (Naseh and Wagner et al. 2019), we conducted the interviews using Skype. Ten leading humanitarian organizations with services for Syrian refugees in Jordan including UNHCR, International Rescue Committee (IRC), Mercy Corps, Caritas Internationalis, United Nations Children's Fund (UNICEF), Norwegian Refugee Council (NRC), Danish Refugee Council (DRC), Finn Church Aid (FCA), and a local NGO were contacted. The agencies' contact persons were briefed about the study and provided with a confidential Skype ID and password. They were encouraged to share the provided confidential Skype ID and password with staff at the managerial level of their organizations who might be interested in participating in the study. Six service providers volunteered to participate and used the provided Skype ID and password to contact the first author and schedule an anonymous interview in September 2017. All interviews with service providers were in English, conducted and recorded through audio calls, and took between 30 and $45 \mathrm{~min}$. Interviews were started with verbal consent and continued with discussions on the living situations of refugees in Amman and refugees' major needs. We asked service providers to tell us about their work, refugees that they have worked with, living conditions of refugees in Jordan, major needs of Syrian refugees, risk and resilience factors for wellbeing of 
refugees, and available services for refugees based on their short-term and long-term needs.

We also analyzed 11 audio-recorded interviews with heads of Syrian refugee households in Amman in this study. These interviews were collected for an exhibition on forced displacement between September and November 2017. All interviews with Syrian refugees were conducted by a peer outreach service provider through purposive sampling. Interviews with refugees were conducted in Arabic and simultaneously translated into English. The interviewer used a topic-based interview guide to collect verbal consent and initiate discussions about the living situations and major needs of refugees in Amman. All interviews began with the biographic-narrative interview method (Wengraf 2001) to construct interviewees' life stories followed by probes and follow-up questions with a focus on reasons for leaving Syria, household characteristics (i.e. number of household members, age, sex, marital status, occupation, and education), living situations in Amman (including access to basics of living, health status, access to education, and access to work and livelihood), major needs, and future plans. Interviews with refugees were solely conducted with individuals self-identifying as the head of the household.

\section{Analysis}

All interviews were transcribed verbatim and inductively analyzed using the thematic analyses method (Braun and Clarke 2006). To minimize bias, two of the authors (MR, ZA) independently read and re-read the transcribed texts in search of patterns and meanings to generate codes. The long lists of independently generated codes were entered into a thematic matrix by the first author, merging the codes for similar sections of the texts (Ritchie and Lewis 2003). To reach consensus, merged codes were shared and discussed among the two authors who generated the initial codes. To enhance the validity and minimize the bias in reporting results, the first and the fourth $(\mathrm{MN}, \mathrm{ZA})$ authors independently generated themes based on the patterns of the final codes. Peerdebriefing and negative case analysis were used to enhance the rigor of analysis. The generated themes were discussed among four of the authors until a consensus was reached. For each theme, direct quotes from interviews were selected to be reported in the study to demonstrate the relationship between the collected data and reported information, enhancing the validity of results. All reported names are created or altered by the first author to protect the identity of the interviewees. Shared information about sex and age of the interviewees are based on the collected data from the interviews.

\section{Results}

Among the interviewed Syrian refugees eight were female (marital status: divorced $=1$, married $=3$, widow $=4$ ) and three were male (marital status: married $=2$, single $=1)$. The average age of the interviewed refugee was $47(\mathrm{SD}=15.99)$ and the average household size was $4.6(\mathrm{SD}=2.67)$. All interviewees were living in Amman at the time of the interview, but three stated that they have lived in the Zaatari camp between less than a month to 7 months early after arriving in Jordan. The interviewed key informants $(\mathrm{F}=3, \mathrm{M}=3$ ) were staff at international and national NGOs, humanitarian organizations, and United Nations (international NGOs $=3$, national NGO $=1$, United Nations $=1$, international humanitarian organization $=1$ ). Only one of the key informants was originally from Jordan and the rest were international. We found six main themes after coding and comparing the key informants' interviews and refugees' narratives: (1) gap between refugees' expectations and reality of humanitarian services; (2) rent as a major but neglected challenge; (3) older adults: vulnerable and at the back of the queue for services; (4) mental health of adults as an overlooked need; (5) education: hard to access for extremely poor and adults; and (6) an uncertain and unplanned future.

\section{Gap between refugees' expectations and reality of humanitarian services}

A gap was observed between refugees' expectations of humanitarian organizations and what service providers told us about available services. In the narratives of refugees there were demands for services that were not among the named available assistance for urban refugees by key informants. For instance, refugees requested help with rent and utility costs:

We as refugees wish that Caritas or other organizations could just help us by giving us the rent or actually the bills for water and electricity or just pay the rent for one year so I can have some peace of mind, knowing that I can look forward to things and not looking at other things like rent so I can look at other things like working and providing for my family.

Golnar, a 59-year-old Syrian woman

However, key informants' accounts suggested that services for urban refugees were limited to provision of primary education, limited health services, small cash assistance, and different training programs subjected to availability of required financial resources. Refugees seemed to be thankful for the generosity of the Jordanian government in sheltering them, but they were frustrated with humanitarian organizations as most believed 
they were not given the services and protection they were entitled to. For instance, Baran, a 47-year-old Syrian mother living in Amman, talked with a sense of gratitude while mentioning her living experiences in Jordan; she said, "the Jordanian government and the army were very good to us." However, she expressed frustration with the United Nations when talking about services for Syrian refugees, explaining:

I see some people have a better situation than us, the UN helps, and some people who really need help are not being helped.... I've just heard that they [UN] will remove all the assistance for the refugees, the Syrians. I just wish that they would help us.

Similarly, Sabah, 53-year-old mother of six children said:

The Jordanian government understood our situation and they took us... [UNHCR] was protecting us, but now UN give us less vouchers and coupons. Why?... You [UN] said you want to protect us and now you want to send us back to the fire [Syria]? Where is the protection?

While refugees blamed humanitarian organizations for neglect in service provision, key informants proudly counted a variety of health, education, and livelihood services, which were almost exclusively for refugees residing in camps, specifically in the Zaatari and Azraq camps. Key informants named free primary schooling, basic health care services, life skill training for children, medical services, livelihood assistance such as cash for work, and cash assistance among the services for Syrian refugees in Jordan.

Health care services inside the camp are very wide... for health services there are around seven big hospitals inside Zaatari camp and bunch of clinics that run by other organizations...They [hospitals in camps] have all of the services but severe cases, for example, like heart attack or cancer or any severe health case, will be referred by the ministry [of health]... There is a contract between the hospitals in the camps and the hospitals in Jordan.

Victoria, an officer at an international humanitarian organization in Jordan

Three of the refugees in our sample had lived in the Zaatari camp upon arrival to Jordan, but all left due to an array of reasons including experiences of harassment, lack of privacy, shared bathrooms and kitchens, lack of access to cellphones, and substandard housing:

It [living in Zaatari camp] was very bad; troubles and harassment; if there were any mistakes or any troubles, they accused everyone... People live very close to each other's tents; no privacy at all. We had to wait and in line to use the bathroom.

Fatima, a Syrian mother of five children

Key informants believed that living conditions in camps have improved in recent years and now refugees are more willing to stay in camps. Ava, a key informant working for one of the offices of the United Nations, explained, "tents were phased out quite early [in Zaatari camp]... They [refugees] are now in what we call locally Caravans, but they [Caravans] are prefabricated units." Key informants also mentioned that refugees in camps have access to some incentives that encourage them to stay:

In order to encourage the refugees to stay in the camps, the UNHCR decreased this amount [cash assistance] for refugees living outside the camps. You know? So, for them [refugees], it's better to stay in the camps regardless of the problems. You can get lots of benefits, you can get this [cash assistance] 23 JDs [Jordanian Dinars] per person. You can get your winter kits. Your, mmm, all other aids for free. Besides, inside the camps you have the privilege of a cash for work system.

Leila, a humanitarian worker at an international NGO

The decrease in the cash assistance for urban refugees seemed to frustrate them rather than encouraging them to live in camps. In our sample, none of the refugees expressed an intention to live in camps, citing their concerns about restrictions and lack of privacy, which seemed to remain a problem despite recent improvements in camps. Ava, a key informant working for one of the offices of the United Nations, said "there is no internet access for refugees [inside the camps], the network is jammed by the government, so there is no communication." Noah, senior coordinator at an international NGO, explained the restrictions in leaving the camps for refugees and stated "the leave permit [permission to leave the camps] is so difficult ... they accept the leave permit [in Azraq camp] only for the urgent cases and sometimes even the urgent cases are not allowed a leave permit." Moreover, key informants told us that the new refugee housing units, Caravans, still lack bathrooms and kitchens; therefore, refugees must share cooking facilities, toilets, and bathrooms.

Lack of knowledge about available services was clear in the narratives of refugees. Most of the refugees in our study believed that "others" receive more and better services and the majority believed that humanitarian organizations withhold services from them, which resulted in 
frustration. Refugees referred to what they had seen in social media or heard from their friends as a source for these claims. Golnar, a 59-year-old Syrian woman, said "we see on the social media and websites people getting this and getting that, getting help from all these organizations, and us getting none, and this makes me feel sorry for myself and about my living situation." Zara, a 47-year-old Syrian woman, stated "we are the people that they refused to help in the UN, we are very patient, and we went through a lot."

\section{Rent as a major but neglected challenge}

In refugees' narratives, high cost of rent was mentioned in almost all interviews as the most important challenge of living in Jordan. For instance, Golnar, a 59-year-old Syrian woman who fled Damascus, said "the worst thing that troubles us is the house rents." In order to afford rent, refugees in our study commonly lived with extended family members in overcrowded, old, and substandard housing. Some had to do chores for the landlords to cover part of the rent, and many had to borrow money or sell their belongings to avoid eviction.

We are three families living under one roof ... I sleep on the floor as well as my grandchild, and for the youngsters [her children], they sleep on the beds... the rent is paid by all of us, we just collect as much money as we can, and we pay, and sometimes we can't even pay the full rent, so we must pay part of it, and sometimes I fall in debt with some people... it's just very hard to pay rent here... I actually sold a lot of my personal items and a lot of my personal items have been sold so I can pay the rent and that's how we pay the rent, just by borrowing money and selling items.

Golnar, a 59-year-old Syrian woman

In replying to a question about major needs of Syrian refugees, two key informants briefly acknowledged rent as a challenge with no reference to a long-term plan to address the problem. Arya, a key informant working at a local humanitarian organization, said "sometimes the UN gives them vouchers for food; they try sometimes to sell these vouchers to pay the rent." This is concerning as in several interviews, refugees told us that they cannot afford to eat enough and have experienced hunger. Another key informant stated:

If they are eligible, every beginning of the month I think there is a SMS from UNCHR that says we have deposited in your account the amount of 100 JD, equivalent to 140 U.S. dollars more or less. The person in charge, let's say the head of the family, the father or the mother will go to an ATM machine of a bank that UNCHR works with and using the eye-print, he or she can withdraw the money that was deposited into their bank accounts... This money is mainly used to pay for the house rent because that's the bigger concern, the main concern for the families.

James, an officer at an international NGO in Jordan

This multi-purpose cash assistance is designed to give refugees a choice in how to use the money, but it seemed insufficient to cover the rent cost. For instance, Ghufran, a 36-year-old single man from Damascus told us that he is paying JD 150 per month for his room. Most refugees had no contract for their housing, which put them in a more vulnerable position. Refugees reported experiences of harassment from landlords and one refugee explained that she became homeless after her landlord took all her belongings for the unpaid rent and left her in the street.

\section{Older adults: vulnerable and at the back of the queue for services}

Older adult refugees (age 60 and above) were far more vulnerable in the analyzed narratives. We had three older adult refugees in our sample, Nabil $76(\mathrm{M})$, Darya 65 (F), and Arzu 60, (F), they all lived with multiple health issues and spent most of their time at home, isolated from society. Nabil, a 76-year old Syrian man, stated "I have a back problem and everything else...My wife is sick. She has heart problems and spasms... they [health service providers] took three hundred [JD] from me for three shots for my wife's treatment... How can I pay for my rent and medication?" Older adult refugees rarely reported receiving any humanitarian assistance, and it seemed that in the absence of family support, they were dealing with their problems alone.

My husband passed away here in Jordan, and we sent him back. Now I live by myself under the stairs, I don't have even one penny... I don't have a heater or blankets... I don't have anybody here. I live under the stairs. My situation is very bad. And this winter, the neighbors brought me a big plate [of food]. I don't have a bathroom... I don't receive anything from the UN, no assistance whatsoever... I don't have a house, I live under the stairs. She let me stay [under her stairs] for one month, the neighbor. Only one month... After my husband died, I didn't have anything. We lived in hospitals pretty much. After that, I didn't have any more money. The man that we used to stay with before, he [the landlord] took everything. All I came out with was the clothes that I was wearing.

Darya, a 65-year-old refugee widow 
Most of the services or plans for refugees mentioned by key informants were focused on refugee children and younger adults. Almost no reference was made by key informants to any programs that specifically served older adult refugees in Jordan. Some of the general services for refugees also seemed difficult to access for older adults. For instance, the UNHCR cash assistance requires registration, a cellphone to receive notice of payment, and physical mobility as the cash is only available using eye-print at specific ATM machines.

\section{Mental health of adults as an overlooked need}

The majority of adult refugees in our sample had lost their belongings in Syria, most had lost a friend or a family member in the war, and some had friends or family members detained in their home country. For instance, Golnar, a 59-year-old Syrian woman, said "my son died in the war, so I got my grandchildren into Jordan." Moreover, interviewed refugees referred to multiple trauma experiences in their journeys from Syria to Jordan. For example, Asmaa, a 23-year-old widow, said "they [Syrian armed forces] took my husband and started bombing us, my son was 30 days old... I couldn't bring anything, I couldn't bring diapers or milk, there was no way for me to feed my child." She added "they [government forces in Syria] violated women... we saw so many things; ugly things; ... they were very dangerous; they [Syrian armed forces] were holding knives and even the men were too scared of them."

Signs of hopelessness, trouble sleeping, and frustration were common in the narratives of refugees. For instance, Ghufran, a 36-year-old single Syrian man, said "I used to think a lot in the past about my goals, but now... I don't like to dream anymore." Zara, a 47-year-old Syrian mother, said "he [her son] is supposed to be in school but there is a problem. He didn't sleep before and now he started sleeping." Ahmad, a 31-year-old father of two, said "I see sometimes she [my mother] breaks, when I wake up, I see her crying and she is talking to herself."

Key informants referred to mental health services for children and teenagers, but healthcare services for adult refugees seemed to be based on self-referral. Syrian refugees in our sample were consumed by concerns about their families' basic needs such as shelter, food, and education for children, and, consequently, mental health or mental health services were not a priority for them. Nancy, a key informant working for an international humanitarian organization, said "I didn't meet anybody who came here for mental health problems. I know that there are people who are sick ... but I rarely came across people for you know trauma and things like that."

Key informants reported high levels of resilience among Syrian refugees in Jordan despite the past trauma experiences and hardships of living in exile. Noah, senior coordinator at an international NGO, said "you can see how resilient they are... despite all of the things, they decided to continue living. They started opening their shops. They started painting their Caravans. They even started small gardens around the Caravans." Key informants named available services provided by humanitarian organizations as the most important protective factors for refugees in Jordan. However, refugees referred to their families, specifically their children, and religious beliefs as their source of resilience. For instance, Fatima, a 32-year-old Syrian mother, said, "My family and I together, that's the most important thing." Ahmed, a 31-year-old father, said "my children keep me going." In multiple interviews refugees stated that a higher power would solve their problems and some mentioned that their beliefs help them to manage their stress. For instance, Zara, a 47-year-old Syrian mother, said "God's power is what keeps us strong" and Golnar, a 59-year-old Syrian grandmother, said "I am a very religious person, anything that I feel challenged by, anything every day, I just go to God and that would make me feel spiritually relaxed and ready to face the days."

\section{Education: hard to access for extremely poor and adults}

In the interviews that we collected, educational programs were among the limited available capacity building services for Syrian refugees and mainly focused on children. Almost all key informants in our sample indicated that some sort of educational program is provided by their organization for refugee children. Similar to other services, educational programs were more accessible in refugee camps for Syrian children.

They [schools] are available in camps. It [Zaatari camp] has close to thirty schools inside the camp. All of them [schools] are managed and run by the Ministry of Education and the teachers are recruited by the Ministry of Education, the curriculum is the same as any other Jordanian school.

Ava, an officer in one of the offices of the United Nations in Jordan

The majority of refugees that we interviewed stated that their children were attending school in Jordan; however, some had children not in attendance. Key informants named early marriage, poverty, disability, child labor, and lack of familiarity with the education system in Jordan as main reasons for school dropouts among Syrian children. Refugees referred to fees associated with education as the main barriers preventing them from sending their children to school. Yara, whose five children were collecting plastic and cans in the streets of Amman to support their family at the time of interview, explained: 
"If I register my children in a school in Mafraq, I have to pay $20 \mathrm{JD}$ for each to [take] the bus. I don't even have enough money to feed them; how can I pay for transportation? In the beginning, two of my children registered in the school, [they attended] for two months and then they quit."

Yara, a young mother from Syria

Some organizations had targeted programs to prevent school dropouts by providing incentives, covering transportation expenses, and delaying child marriage. Moreover, some had educational programs for out-ofschool children to help them return to school. However, the targeted programs mentioned in the interviews were small in scale and subject to availability of seasonal funds. Key informants told us that most of the funds that they receive for Syrian refugees are short-term, preventing them from long-term planning in Jordan. Nancy, a key informant working for an international humanitarian organization, stated 'they [international humanitarian organizations] were going to cut schooling [for Syrian refugees] because of lack of funding ...it's a problem you know that probably year by year, maybe semester by semester, they have to see if they are going to have funds."

Some refugees also expressed concerns about the quality of the education in Jordan. Fatima, a 47-year-old refugee who fled from Daraa in Syria, said "the education for the kids is free; but I don't see them getting or understanding... we enrolled them there [in the school] and after the Jordanian education program, I don't think they have anything proper, or convenient. It's [the education] not official."

Although the level of education was generally low among the adult refugees in our sample (high school, except in the case of one refugee who had a college degree), educational opportunities for adults were rarely mentioned in the interviews with key informants and when mentioned, these programs were part of smallscale projects or projects with short-term funding. For instance, Noah, a senior coordinator at an international NGO, said "higher education is not [free]. However, each year, the UNHCR offers scholarships for Syrian refugees. To be honest, it's a shame; 45 scholarships for the millions or so. It's very limited."

\section{An uncertain and unplanned future}

On average, refugees in our sample have been in Jordan for 5 years and none of them had expected their exile to last this long. Therefore, most refugees did not invest in a long-term plan for staying in Jordan, instead they were constantly hopeful for the situation to change. Golnar, a 59-year-old Syrian grandmother, said "I was supposed to come to Jordan for one week from Syria, but it got extended from 2013 until now in 2017." Noah, a key informant further explained this situation:

Three years ago, they [refugees] were just waiting to get back to Syria. They were expecting the war will end soon... So, they were less interested in education, less interested in work, less interested in everything... They somehow lost hope that the war will end soon. And they start thinking about settlement, more or less about settlement. You know? About getting a job, about educating their children, about sending them to the cities.

Noah, a senior coordinator at an international NGO

The majority of refugees in our study did not have a plan to return to Syria or stay in Jordan, instead they were hoping for resettlement in a Western country in an uncertain future with a dream for a better life. Most of them stated that they have been waiting for years for an interview or approval for resettlement in a third country, but none knew how much longer they would have to wait. James, one of the key informants in our study, said "when we interview them [Syrian refugees], the majority would like to emigrate, to go to Europe, to go to the U.S., Canada or Australia" and later added that resettlement to one of these countries can take years and Syrian refugees in Jordan have a slim chance for this option. A Syrian refugee whose request for resettlement in a third country was rejected told us:

I would love to go to America or any other European country, and I've tried, I'm waiting for an answer, but we don't know yet, but we'll see, hopefully it's all good to go to America. I'd also love to go to Canada or Australia, or Copenhagen, mostly because of my English, you know, I don't want to have to learn like French... I just want to go to a country that speaks English and I can just move in with the society and just have a better life.

Ghufran, a 36-year-old single Syrian man

Few refugees in our sample expressed an interest in return, but similar to those who wanted to resettle in another country, they did not know when or how. Darya, a 65-yearold homeless Syrian widow, said "I want to stay here and see what happens... if the situation in Syria gets better, yes [I want to return to Syria]. Who doesn't want to go back to her country?" Surprisingly, Arya, a key informant working for a local humanitarian organization, told us 'recently many Syrians go back to Syria as they [government of Jordan] opened the borders. It is not still completely safe in Syria, but many Syrians went back there."

Key informants believed that uncertainty about the future is one of the main challenges for Syrian refugees in 
Jordan. For instance, James, an officer at an international NGO in Jordan, said "the main concern here is uncertainty, they [refugees] are uncertain, they don't know what tomorrow is having for them" and Nicole, a key informant working for an international humanitarian organization, added "what's gonna happen in Syria, what's next in Syria, it's confusing them [Syrian refugees] in forming their decision for the future." Key informants also told us that the majority of Syrian refugees in Jordan have limited access to transparent information about the situation in Syria.

\section{Discussion}

The state of conflict in the Middle East, the overwhelming humanitarian needs in different countries including Syria and its neighboring countries, and limited resources have placed refugees in a highly vulnerable position (Fisseha 2018). The majority of refugees in our sample seemed to be ill-informed about available humanitarian resources and eligibility criteria for accessing these services. Consequently, they perceived the distribution of services in the urban areas as unfair, random, and insufficient. Refugees mentioned that they heard from other refugees or saw on social media that "others, " but not them, received humanitarian services. When talking about the available services, key informants made a clear distinction between available services in camps versus services for the urban refugee population. However, interviewed refugees did not seem to consider themselves as a separate group. Throughout the interviews, Syrian refugees demanded different services while considering themselves deserving to receive them as refugees and blaming humanitarian organizations for not providing these services as responsible entities. This observation partly affirms the findings of previous studies (Aziz et al. 2019; Culbertson et al. 2016), suggesting that Syrian refugees are not involved in decision making in resource allocation that could directly impact them. For instance, while urban refugees in our sample were desperate for humanitarian services, almost all resources named by service providers in the interviews were exclusively for refugees in camps.

The majority of refugees in Jordan live in the urban areas. Lack of privacy due to communal cooking, toilet, and bathing facilities and lack of access to information due to the government's decision to disable mobile phones (using signal jammers and blockers) in camps have been among major challenges forcing many refugees to leave camps in Jordan (Wall et al. 2017). It is unclear if the interviewed refugees were aware of the recent improvements discussed by key informants in the camps, but none showed any interest in leaving the urban areas to live in camps. Moreover, our findings suggest that challenges that refugees identified in camps have remained unsolved despite the recent improvements since the new and upgraded housing units in camps still lack private toilets and cooking areas.

The influx of Syrian refugees in the urban areas in recent years has resulted in rent prices being tripled or even quadrupled in some areas in Jordan (Achilli 2015; Al-Qdah and Lacroix 2017; Aziz et al. 2019). According to a report published by NRC in 2015, Syrian families were paying around 150 JD per month for accommodation in Jordan (NRC 2015). The lack of affordable housing has forced many refugees to live in sub-standard housing such as small apartments, garages, or even tents (Culbertson et al. 2016). Refugees in our sample referred to difficulties in paying rent as one of their major challenges in Jordan. They also referred to a lack of access to an official lease or rental contract for their apartments. Over $90 \%$ of non-camp Syrian refugees in Jordan rent their residence in the private market (Tiltnes et al. 2019). Many landlords in Jordan refuse to sign an official lease or contract with refugees to be able to increase the rents or evict them easily (Culbertson et al. 2016). These challenges put refugees, specifically more vulnerable groups such as older adults, at a greater risk of harm. In our sample, older adults discussed several challenges including homelessness.

Lack of mobility, weakened physical strength, and social isolation can put older adult refugees in more vulnerable positions (Strong et al. 2015). Older adult refugees are usually recognized as vulnerable groups by humanitarian organizations and often have priority in receiving certain services. For instance, older Syrian refugees in Jordan are recognized as refugees with "vulnerability characteristics"; therefore, they can receive World Food Programme (WFP) food support, which is provided in camps (Krafft et al. 2019). Older adult refugees' needs in our sample seemed to be beyond the scope of the programs and services discussed by the key informants. Moreover, many of the services discussed seemed to be unfit to reach or serve older adults. For example, older adult refugee women do not have access to cell phones; often, men are the ones with a phone in Syrian communities (Wall et al. 2017). Yet, it seemed that access to a cell phone to receive a notification and having the mobility to reach specific ATMs were required for refugees to receive cash assistance in Jordan.

Signs of stress, frustration, and hopelessness were common in the narratives of refugees in our sample. Similar to refugees in comparable situations across the globe, the majority of Syrian refugees have faced war, violence, persecution, and loss or killing of family members and close friends before arriving in Jordan, and many have experienced a life-threatening journey to this country as they had to rely on smugglers (Crumlish and O'Rourke 2010; Naseh and Macgowan et al. 2019; 
Rizkalla and Segal 2018). They also encounter multiple stressors in Jordan such as poverty, day-to-day discrimination, isolation, and micro-aggressions (Abu Hamad et al. 2017; Rizkalla and Segal 2018; Weinstein 2000). As a result, mental health problems are common among Syrian refugees in Jordan (Abu Hamad et al. 2017; Gammouh et al. 2015; Jabbar and Zaza 2016; Rizkalla and Segal 2018). Service providers in our sample described Syrian refugees as a very resilient group and focused on refugees' mental strengths rather than mental health issues while discussing refugees' needs in Jordan. However, their resilience should not be misinterpreted as absence of mental health issues. Reports suggest limited access to mental health services for Syrian refugees in Jordan (Aziz et al. 2019; Jabbar and Zaza 2016) and our findings imply that these limited services are only available to those who seek them.

Syrian refugees in Jordan are in protracted exile, which is predicted to continue (Aziz et al. 2019; Culbertson et al. 2016). In this context, long-term investment in capacity building programs, especially education is important. Our findings suggest that Syrian refugees, in particular, children, have access to education in Jordan. In order to accommodate Syrian children, Jordan has started double-shift schools, offering mostly afternoon shifts to Syrian children (Aziz et al. 2019). However, recently published data suggest that despite access, less than $60 \%$ of Syrian refugee children attend schools in Jordan (Human Rights Watch 2018; Jabbar and Zaza 2016). As discussed by both refugees and key informants in our study, school dropouts among Syrian refugee children could be the result of poverty and fees associated with education. Key informants mentioned some targeted programs to prevent school dropouts, but discussed services were small in scale and dependent on availability of short-term funds. Short-term funding policies have been discussed in the previous studies among the main challenges preventing humanitarian organizations from long-term planning and implementation of capacity building programs for Syrian refugees in Jordan (Aziz et al. 2019; Culbertson et al. 2016). Many NGOs or humanitarian organizations rely on voluntary donations for their service provisions, which creates uncertainty about possibility of continuation of services.

In this study, Syrian refugees' plans for the future seemed to be inconsistent with their protracted exile. Most of the refugees in our study told us that since they arrived in Jordan, they have been waiting to see what will happen. This means that for close to a decade, most of them have been waiting to be resettled in another country and a minority have been waiting for the war to end and return to Syria. None of the refugees in our sample referred to any plan to invest in their quality of life in Jordan. On the global scale, in 2018, only $4.7 \%$ of the refugees in need of resettlement were actually resettled (UNHCR 2019). As mentioned by service providers in this study, resettlement can be a lengthy and hard to reach durable solution for the majority of Syrians in Jordan.

\section{Limitations}

Small sample size and the qualitative nature of the study limit the generalizability of the results. Although a limitation, generalizability of the results in its traditional sense was not the goal of this phenomenological study; rather, this study aimed to understand lived experiences of refugees and compare refugees' perspective with service providers' viewpoint about major needs and the future plans. The focus of this study was on the urban Syrian refugee population in Amman. However, in the interviews, key informants focused on humanitarian services in camps rather than urban areas. Although this is an important observation that highlights more attention is given to refugees living in camps, this digression from the main focus of the study, urban refugees, might have caused a disconnect.

\section{Conclusions and recommendations}

Refugees in our sample seemed to be misinformed about the available services and frustrated that they were denied the services that "others" received. Humanitarian organizations could be more proactive in the provision of accurate information about their available resources and eligibility criteria for assistance. Social media content produced by most of the humanitarian organizations mainly features services provided and any content that would be appealing to donors. Such content seems to disappoint refugees who did not receive the suport promoted in the social media platforms. Humanitarian organizations can use social media messages targeted for refugees to communicate accurate information, specifically to community leaders in Jordan. Previous studies found that many Syrians keep their cell phones even at the expense of other needs as it is viewed as a tool helping to challenge the government in Syria as well as a tool to stay in contact with friends and families (Wall et al. 2017). Humanitarian organizations can communicate accurate information directly to refugees using text messages.

Our findings suggest that more targeted programs are needed for urban refugees and older adults. Although there might be impediments in providing services to refugees outside of camps, humanitarian organizations should make efforts to consider refugees' priorities for those living in urban areas. Replacing traditional campbased responses, where possible, with alternative durable solutions can create possibilities for refugees to live with greater dignity as members of the community (UNHCR 
2014). In terms of tailored services for older adult refugees, their social isolation and lack of mobility should be taken into consideration. Outreach programs and home visits would be more effective in reaching older adults compared to mainstream services.

Among much-needed services for urban refugees in our sample was access to affordable housing. While cash assistance and cash transfer help refugees with paying rent (Hagen-Zanker et al. 2018; Lee 2019), these interventions cannot prevent increases in rent costs or abuse by landlords. As a solution, cash assistance for rent could be transferred directly to landlords with an agreement between homeowners and humanitarian organizations, guaranteeing protection for refugees and fixed rents for longer periods of time (Naseh et al. 2018). There are also small-scale innovative practices that could be replicated to enhance refugees' access to affordable housing. For instance, NRC provides funding for landlords to renovate their houses in Jordan in exchange for housing Syrian refugees for 1 year (Culbertson et al. 2016). By providing funds for landlords NRC invests in local communities and by conditioning the fund to housing refugees the project invests in integration and access to shelter in the short-term (Culbertson et al. 2016). In the long-term, investment is needed in Jordan's housing market to fulfill the unmet demand for affordable housing.

Moreover, among the much-needed services for refugees are mental health services. Considering the perceived stigma toward mental health problems, many refugees might hide their mental health needs or avoid seeking help. Therefore, outreach programs are needed together with awareness-raising sessions about the importance of mental health. Awarenessraising about living in protracted exile and return as the most accessible durable solution is also needed for refugees. Such awareness-raising programs or any capacity building activity for Syrian refugees in Jordan requires long-term investment and planning. Although humanitarian organizations commonly receive their funding annually, donors should consider commit to long-term funds with long-term goals, allowing specific capacity building programs (Culbertson et al. 2016). Investment in capacity building of Syrian refugees, specifically education, can also have positive implications in rebuilding Syria after the war in the future, as more economically successful and empowered refugees are more likely to return to their country of origin to rebuild it (Aziz et al. 2019).

\section{Abbreviations}

DRC: Danish Refugee Council; FCA: Finn Church Aid; IRC: International Rescue Committee; NGO: Non-governmental organization; NRC: Norwegian Refugee Council; UNHCR: United Nations High Commissioner for Refugees;

UNICEF: United Nations Children's Fund

\section{Acknowledgements}

We would like to thank Dr. Naisy Sarduy for her help in submitting the institutional review board request, Caritas Jordan for the help in recruiting refugees for the sample, Fatima Al-Saedi and Mohammad Al-Sukker for their help in data collection, and Mousa Hanani for volunteering as an interpreter during the interviews.

\section{Authors' contributions}

MN and NL conceived the idea of this study. MN conducted the interviews with service providers, merged the codes using the thematic matrix, and drafted the paper. ZA and MR transcribed and coded the interview. MP provided major contributions to the final manuscript. All authors read and approved the final manuscript.

\section{Funding}

Not applicable

\section{Availability of data and materials}

Interested researchers can contact the first author for data requests.

\section{Competing interests}

The authors declare that they have no competing interests.

\section{Author details}

${ }^{1}$ School of Social Work, Portland State University, Portland, USA. ${ }^{2}$ Department of Politics \& International Relations, Florida International University, Miami, USA. ${ }^{3}$ Robert Stempel College of Public Health and Social Work, School of Social Work, Initiative on Social Work and Forced Migration, Florida International University, Miami, USA. ${ }^{4}$ Robert Stempel College of Public Health and Social Work, School of Social Work, Florida International University, Miami, USA.

Received: 17 March 2020 Accepted: 28 October 2020

Published online: 07 November 2020

\section{References}

Abu Hamad B, Jones N, Samuels F, Gercama I, Presler-Marshall E, Plank G, Essaid A (2017) A promise of tomorrow: The effects of UNHCR and UNICEF cash assistance on Syrian refugees in Jordan. Available via Overseas Development Institute. https://www.odi.org/publications/10978promise-tomorrow-effects-unhcr-and-unicef-cash-assistance-syrianrefugees-jordan. Accessed 16 Mar 2020

Achilli L (2015) Syrian Refugees in Jordan: A Reality Check. Migration Policy Centre. Policy Briefs. https://doi.org/10.2870/821248 2015/02

Al-Qdah TAK, Lacroix M (2017) Syrian refugees in Jordan: Social workers use a Participatory Rapid Appraisal (PRA) methodology for needs assessment, human rights and community development. Int Soc Work 60:614-627. https://doi.org/10.1177/0020872816673889

Aziz S, Gardner J, Anaie T, Rana O (2019) Towards Sustainability and Empowerment: Reforming America's Syrian Refugee Policy. Rutgers Center for Security, Race and Rights, Newark

Boswall K, Al Akash R (2015) Personal perspectives of protracted displacement: An ethnographic insight into the isolation and coping mechanisms of Syrian women and girls living as urban refugees in northern Jordan. Intervention 13:203-215

Braun V, Clarke V (2006) Using thematic analysis in psychology. Qual Res Psychol 3:77-101. https://doi.org/10.1191/1478088706qp063oa

Connable B (2015) From Negative to Positive Stability: How the Syrian Refugee Crisis Can Improve Jordan's Outlook. Available via RAND Corporation, National Defense Research Institute Santa Monica United States. https://apps. dtic.mil/dtic/tr/fulltext/u2/1000195.pdf. Accessed 16 Mar 2020

Creswell JW, Poth CN (2018) Qualitative inquiry and research design, choosing among five approaches, 4th edn. SAGE, London

Crumlish N, O'Rourke K (2010) A systematic review of treatments for posttraumatic stress disorder among refugees and asylum-seekers. J Nerv Ment Dis 198:237-251. https://doi.org/10.1097/NMD.0b013e3181d61258

Culbertson S, Oliker O, Baruch B, Blum I (2016) Rethinking Coordination of Services to Refugees in Urban Areas: Managing the Crisis in Jordan and Lebanon. Rand Corporation, Santa Monica

Fisseha M (2018) The roles of the civil society and international humanitarian organizations in managing refugees crisis in the Middle East and North Africa 
(MENA) region. J Mediterr Knowledge 3:61-80. https://doi.org/10.26409/ 2018JMK3.1.04

Gammouh OS, Al-Smadi AM, Tawalbeh LI, Khoury LS (2015) Chronic diseases, lack of medications, and depression among Syrian refugees in Jordan, 2013-2014. Prev Chronic Dis 12:140424. https://doi.org/10.5888/pcd12.140424

Hagen-Zanker J, Ulrichs M, Holmes R (2018) What are the effects of cash transfers for refugees in the context of protracted displacement? Findings from Jordan. Int Soc Secur Rev 71:57-77

Hamdan-Mansour AM, Abdel Razeq NM, AbdulHaq B, Arabiat D, Khalil AA (2017) Displaced Syrian children's reported physical and mental wellbeing. Child Adolesc Mental Health 22:186-193. https://doi.org/10.1111/camh.12237

Human Rights Watch (2018) World Report 2018-Jordan. https://www.hrw.org/ world-report/2018/country-chapters/jordan. Accessed 16 Mar 2020

Jabbar SA, Zaza HI (2016) Evaluating a vocational training programme for women refugees at the Zaatari camp in Jordan, Women empowerment: A journey and not an output. Int J Adolesc Youth 21:304-319. https://doi.org/ 10.1080/02673843.2015.1077716

Krafft C, Sieverding M, Salemi C, Keo C (2019) Syrian refugees in Jordan: Demographics, livelihoods, education, and health. In: Economic Research Forum Working Paper Series, No 1184 Available via Economic Research Forum. http://erf.org.eg/wp-content/uploads/2018/04/1184_Final.pdf. Accessed 10 June 2020

Lee J (2019) Cash Transfers in Emergencies. In: Columbia Social Work Review, vol 3, pp 21-32

Morris MW, Leung K, Ames D, Lickel B (1999) Views from inside and outside: Integrating Emic and Etic Insights about Culture and Justice Judgment. Acad Manag Rev 24:781-796. https://doi.org/10.2307/259354

Norwegian Refugee Council (2015) In search of a home: Access to adequate housing in Jordan. Available via NRC. https://www.nrc.no/globalassets/pdf/ reports/in-search-of-a-home.pdf

Naseh M, Potocky M, Stuart PH, Pezeshk S (2018) Repatriation of Afghan refugees from Iran: a shelter profile study. J Int Humanit Action 3:13. https://doi.org/ 10.1186/s41018-018-0041-8.

Naseh M, Macgowan MJ, Wagner EF, Abtahi Z, Potocky M, Stuart PH (2019) Cultural adaptations in psychosocial interventions for post-traumatic stress disorder among refugees: A systematic review. J Ethnic Cult Divers Soc Work 28:76-97. https://doi.org/10.1080/15313204.2019.1570891.

Naseh M, Wagner EF, Abtahi Z, Potocky M, Zahedi L (2019) Prevalence of and risk factors for substance use among Afghan refugees in Iran: An exploratory study. J Ethn Subst Abuse. https://doi.org/10.1080/15332640.2019.1571976.

O'Rourke J (2014) Education for Syrian refugees: The failure of second-generation human rights during extraordinary crisis. Albany Law Rev 78:711

Ritchie J, Lewis J (eds) (2003) Qualitative Research Practice: A Guide for Social Science Students and Researchers. SAGE, London

Rizkalla N, Segal SP (2018) Well-Being and Posttraumatic Growth Among Syrian Refugees in Jordan. J Trauma Stress 31:213-222. https://doi.org/10.1002/jts.22281

Rubin A, Babbie E (2016) Essential research methods for social work, 4th edn. Cengage Learning, Boston

Strong J, Varady C, Chahda N, Doocy S, Burnham G (2015) Health status and health needs of older refugees from Syria in Lebanon. Confl Heal 9:12. https://doi.org/10.1186/s13031-014-0029-y

The Regional Refugee and Resilience Plan for the Syria crisis (2018) Regional Strategic Overview: Regional Refugee \& Resilience Plan (3RP) 2019-2020. Available via 3RP. http://www.3rpsyriacrisis.org/. Accessed 16 Mar 2020

The Statistical, Economic and Social Research and Training Centre for Islamic Countries (2016) Humanitarian needs of Syrian refugees: Challenges of the Neighbourhood Countries. SESRIC Available via SESRIC. http://www.sesric. org/files/article/543.pdf. Accessed 16 Mar 2020

Tiltnes AA, Zhang H, Pedersen J (2019) The living conditions of Syrian refugees in Jordan, results from the 2017-2018 survey of Syrian refugees inside and outside camps. Fafo Institute Available via Relief Web. https://reliefweb.int/ report/jordan/living-conditions-syrian-refugees-jordan-results-2017-2018survey-syrian-refugees. Accessed 16 Mar 2020

UNHCR (2014) Policy on alternative to camps (UNHCR/HCP/2014/9). http://www. unhcr.org/5422b8f09.html. Accessed 16 Mar 2020

UNHCR (2015) States Parties to the 1951 Convention relating to the Status of Refugees and the 1967 Protocol. https://www.unhcr.org/protect/ PROTECTION/3b73b0d63.pdf. Accessed 16 Mar 2020

UNHCR (2019) Less than 5 per cent of global refugee resettlement needs met last year. https://www.unhcr.org/news/briefing/2019/2/5c6bc9704/5-centglobal-refugee-resettlement-needs-met-year.html. Accessed 16 Mar 2020
Wall M, Otis Campbell M, Janbek D (2017) Syrian refugees and information precarity. New Media Soc 19:240-254. https://doi.org/10.1177/ 1461444815591967

Weinstein HM (2000) Physical and Psychological Health Issues of Resettled Refugees in the United States. Journal of Refugee Studies 13:303-327. https://doi.org/10.1093/jrs/13.3.303

Wells R, Steel Z, Abo-Hilal M, Hassan AH, Lawsin C (2016) Psychosocial concerns reported by Syrian refugees living in Jordan: Systematic review of unpublished needs assessments. Br J Psychiatry 209:99-106. https://doi.org/ 10.1192/bjp.bp.115.165084

Wengraf T (2001) Qualitative research interviewing. In: Wengraf T (ed) Interview 'facts' as evidence to support inferences to eventual theorization/ representation models. Sage Publications, Londres, pp 2-15

\section{Publisher's Note}

Springer Nature remains neutral with regard to jurisdictional claims in published maps and institutional affiliations.

\section{Submit your manuscript to a SpringerOpen ${ }^{\circ}$ journal and benefit from:}

- Convenient online submission

- Rigorous peer review

- Open access: articles freely available online

- High visibility within the field

- Retaining the copyright to your article

Submit your next manuscript at $\boldsymbol{\nabla}$ springeropen.com 